\title{
Retrospective analysis of marine growth and relationships to return rates of Penobscot River Atlantic salmon
}

\author{
Miguel F. Barajas, Timothy F. Sheehan, Ruth E. Haas-Castro, Brandon Ellingson, and Katherine E. Mills
}

\begin{abstract}
Beginning in the 1980s, return rates of Atlantic salmon (Salmo salar) to the Penobscot River, Maine, USA, declined and have persisted at low levels. This downturn coincided with similar declines in North American and European Atlantic salmon stocks and with changes in the Northwest Atlantic ecosystem. Previous studies investigated whether early marine growth explained the declines, but results varied, with decreased growth associated with declines in European stocks but not North American stocks. In this study, we evaluate whether growth over the entire marine stage is related to Atlantic salmon marine survival. We constructed a growth time series from scales of returned Penobscot River Atlantic salmon spanning periods of varying marine survival. We used analysis of variance (ANOVA) and post hoc tests to quantify seasonal growth increment differences and principal component analysis to characterize variability among the suite of growth increments. We observed reduced growth during the second winter and second marine year starting in the 1990s, with compensatory seasonal growth relationships. These results indicate that diminished growth during late marine stages is associated with low return rates in this population.
\end{abstract}

Résumé : À partir des années 1980, les taux de retour de saumons atlantiques (Salmo salar) dans le fleuve Penobscot (Maine, États-Unis) ont baissé pour ensuite demeurer faibles. Ce déclin coïncide avec des déclins semblables des stocks nord-américains et européens de saumons atlantiques et avec des changements dans l'écosystème de l'Atlantique Nord-Ouest. Des études antérieures ont tenté d'établir si la croissance en mer expliquait ces baisses, avec des résultats mitigés, dont une diminution de la croissance associée à des déclins dans les stocks européens, mais non dans les stocks nord-américains. Nous avons évalué s'il existe une relation entre la croissance durant l'ensemble de la phase marine et le taux de survie en mer du saumon atlantique. Nous avons constitué une série chronologique de croissance à partir d'écailles de saumons atlantiques de retour dans le fleuve Penobscot couvrant des périodes caractérisées par différents taux de survie en mer. Nous avons utilisé l'analyse de variance et des tests post hocs pour quantifier la variation des incréments de croissance saisonniers et l'analyse en composantes principales pour caractériser la variabilité au sein de la série d'incréments de croissance. Nous relevons une croissance réduite durant le deuxième hiver et la deuxième année en mer à partir des années 1990, marquée par des relations de croissance saisonnière compensatoire. Ces résultats indiquent qu'une croissance réduite durant la phase marine est associée à de faibles taux de retour dans cette population. [Traduit par la Rédaction]

\section{Introduction}

Over recent decades, declines in Atlantic salmon (Salmo salar) populations in both North America and Europe have been associated with large-scale ecosystem changes in the North Atlantic Ocean (Beaugrand and Reid 2003; Jonsson and Jonsson 2004; Beaugrand and Reid 2012; Mills et al. 2013b; Friedland et al. 2014). North American population declines aligned with an oceanographic regime shift in the 1990s, during which an increase in freshwater export from the Arctic strengthened stratification and altered primary and secondary production dynamics (Pershing et al. 2010; MERCINA Working Group 2012). These changes rippled up trophic levels, affecting zooplankton composition and decreasing the quantity and quality of the forage base for Atlantic salmon (Head and Sameoto 2007; Pershing et al. 2010; Mills et al. 2013b; Renkawitz et al. 2015). In more recent years, habitat areas used by Atlantic salmon have experienced warmer sea surface temperatures since the late 1990s, and multiple marine heatwaves have occurred since 2012 (Mills et al. 2013a; Pershing et al. 2018). Over these decades, coherent declines among most North American and European Atlantic salmon populations have occurred and have been associated with changing physical and biological conditions in the ecosystem (Beaugrand and Reid 2012; Mills et al. 2013b; Olmos et al. 2020). The magnitude of decline has been strongest in populations at the southern extent of the range and among cohorts that remain at sea for more than one winter before spawning (ICES 2020).

The southernmost extent of remnant Atlantic salmon populations in North America is Maine, USA (Fig. 1; USASAC 2020). The Penobscot River contains the largest population in the United States, contributing approximately $70 \%$ of all adult returns to the US since 1978 (USASAC 2020). The population is maintained by a long-standing hatchery program and is characterized primarily by two cohorts of spawners that return to spawn after either one (1 sea-winter, $1 S W$ ) or two winters (2SW) at sea, with very few older and repeat spawners. The trajectory of this population has followed that of other North American Atlantic salmon populations, with declines in abundance and productivity that began during

Received 28 May 2021. Accepted 5 October 2021.

M.F. Barajas and K.E. Mills. Gulf of Maine Research Institute, Portland, Maine, USA.

T.F. Sheehan, R.E. Haas-Castro, and B. Ellingson. National Marine Fisheries Service, National Oceanic and Atmospheric Administration, Woods Hole, Massachusetts, USA.

Corresponding author: Katherine E. Mills (email: kmills@gmri.org).

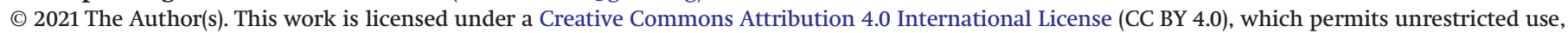
distribution, and reproduction in any medium, provided the original author(s) and source are credited. 
Fig. 1. Map of Penobscot River, Maine, USA, and generalized Atlantic salmon migration routes and feeding areas in the Northwest Atlantic Ocean (adapted from Borggaard et al. 2019 and Reddin 1988). Sea surface temperatures (SST) were retrieved from the area bounded by the straight black lines. Base map source from World Bank, map projection NAD27 UTM Zone 19 N. [Colour online.]

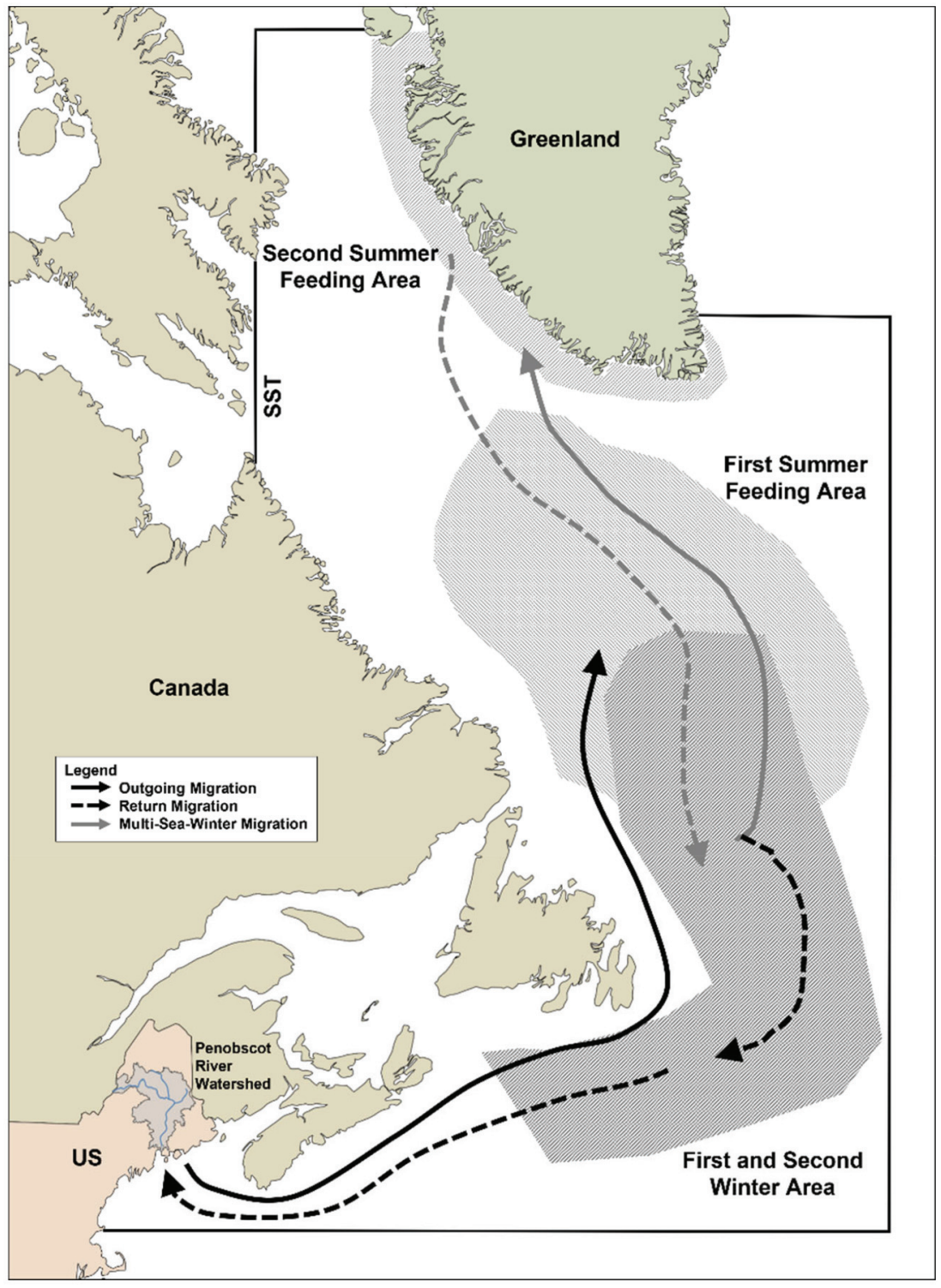

the mid-1980s, which were more substantial for 2SW fish than the 1SW cohort (Fig. 2; Stevens et al. 2019). Currently, this population is listed as endangered under the US Endangered Species Act (74 Federal Register 29344, 19 June 2009), yet riverine habitat restoration and species conservation efforts have not been able to rebuild the population.

Penobscot River Atlantic salmon enter the marine environment via the Gulf of Maine, a dynamic and rapidly changing marine ecosystem (MERCINA Working Group 2012; Friedland et al. 2012; Pershing et al. 2015). These post-smolt salmon then migrate northeast towards summer nursery grounds located in the southern Labrador Sea, where they mix with other salmon stocks from North America (Bradbury et al. 2021). Over the following winter, a portion of these adult salmon mature and return to the Penobscot River to spawn after 1SW. The nonmaturing adult salmon spend a second year at sea, during which they migrate through the northern Labrador Sea to their second summer foraging grounds off the coast of West Greenland (Thorstad et al. 2010). Following their second winter in the Labrador Sea, these 2SW survivors migrate back to the Penobscot River to spawn.

Changes in multiple levels of the Northwest Atlantic ecosystem that include phytoplankton abundance, zooplankton community composition, and capelin abundance and size distribution have been correlated with Atlantic salmon marine productivity and survival, particularly for 2SW fish that are at sea for an extra year compared to their $1 S W$ conspecifics (Mills et al. 2013b). However, the mechanism behind these associations is not fully known, nor is it understood why declines in productivity and abundance have been experienced nearly exclusively in the 2SW cohorts. Renkawitz et al. (2015) hypothesized that changing energy dynamics in the Northwest Atlantic have altered trophic pathways and reduced the energy content of Atlantic salmon diets, thereby influencing their growth, condition, and survival. We propose that this mechanism is linked to the ability of Atlantic salmon to find sufficient and nutritious food, but their at-sea food consumption is hard to observe and measure. However, nutritional quality may be 
Fig. 2. Annual return rates for 1SW (solid line and white circles) and 2SW (solid line and filled circles) Penobscot River Atlantic salmon and annually averaged sea surface temperatures for the Northwest Atlantic Ocean (dotted line and white squares). Outmigration year cohorts included in analyses are shaded: 1978-1980, 1986-1988, 1998-2000, and 2012-2014. (Sea surface temperature data derived from Extended Reconstruction SST version 5; National Oceanic and Atmospheric Administration National Centers for Environmental Information 2017.)

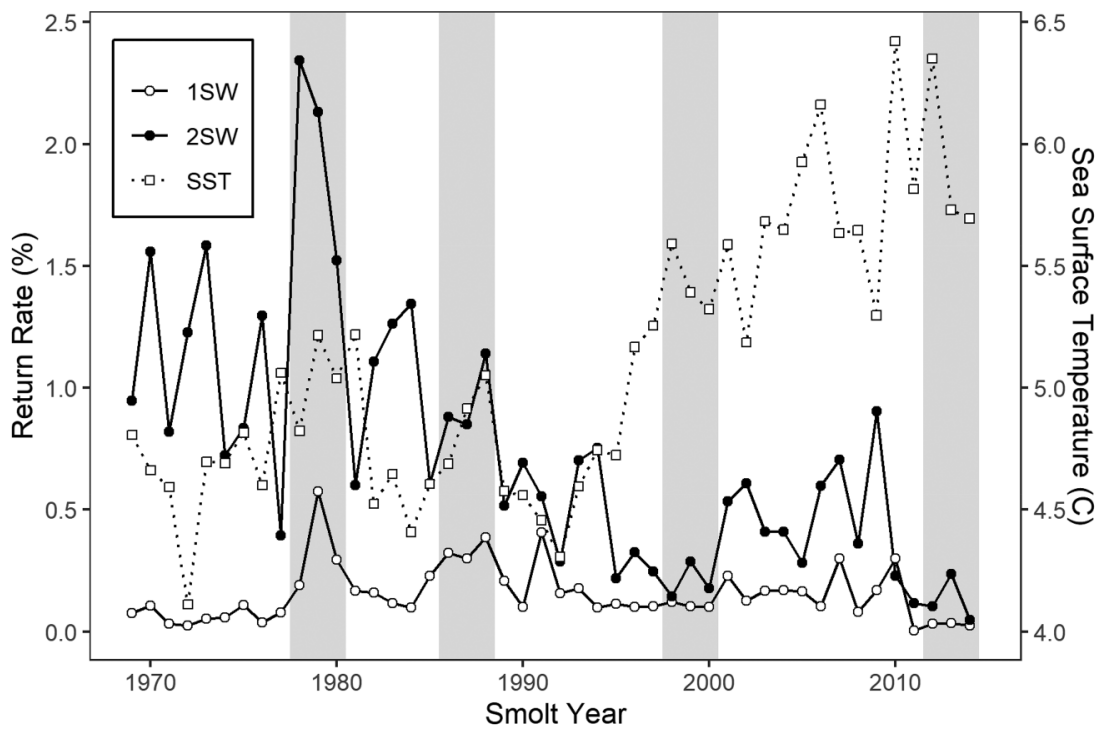

reflected in somatic growth, which can be inferred in temporal detail from growth patterns on fish scales (Doyle et al. 1987; Barber and Walker 1988; Fukuwaka and Kaeriyama 1997). Prior studies using analyses of scale increment patterns suggest that the declines of European stocks are related to decreased growth during the postsmolt phase (Friedland et al. 2000; Peyronnet et al. 2007; Friedland et al. 2009a), whereas scale pattern analyses of North American salmon stocks have concluded that marine survival is growthindependent (Friedland et al. 2009b). These prior studies have only investigated growth through the post-smolt stage (i.e., through the first winter), yet Atlantic salmon may remain at sea for an additional six to eighteen months, during which time growth changes may continue to influence their marine survival.

In this study, we examine patterns of growth over the full marine life stage of Penobscot River Atlantic salmon. This approach enables us to consider growth changes during the latter portions of the at-sea experience that may shape productivity and survival. By looking beyond the post-smolt increment, we also can assess interseasonal growth dynamics for evidence of compensatory or catch-up growth that could aid in identifying periods of poor growing conditions. For $2 \mathrm{SW}$ fish, this full marine analysis will span the summer feeding period off West Greenland, during which changes in consumption and energetics have been identified (Renkawitz et al. 2015) that could pose unique challenges for this cohort during the latter portion of their marine stage. By examining variability in growth over time at sea, indicated by differential intercirculus spacings on scales (Fisher and Pearcy 1990; Shearer 1992), we constructed retrospective growth histories of individual salmon throughout their marine migration (Friedland et al. 1996, 2012; Friedland and Haas 1996; Izzo and Zydlewski 2017). Our aims were to elucidate patterns of variability and change in growth of Penobscot River Atlantic salmon during discrete portions of their time at sea, assess interseasonal growth dynamics, and evaluate whether certain periods of growth are aligned with changes in marine survival. This work seeks to better understand the experience of Penobscot River Atlantic salmon during their time at sea, as poor ocean conditions are hypothesized to be constraining marine survival and limiting the effectiveness of population recovery efforts (NRC 2004; Fay et al. 2006; NMFS and USFWS 2020).

\section{Materials and methods}

\section{Data sources}

Return counts, scale samples and demographic information have been collected from mature Atlantic salmon returning to the Penobscot River by the Maine Department of Marine Resources since the 1970s (MDMR 2018). Fish were sampled at the lowermost dams in the Penobscot River, Veazie Dam, prior to its removal in 2013 and more recently at the Milford fish lift. Returning salmon are counted, and a subset of returns are measured for length, noted if hatchery-reared or naturally reared, and several scales are collected from the left side above the lateral line and on a line extending from the edge of the dorsal fin to the anal fin on each fish. From these archived scales, we selected four groups of years to characterize changes in growth patterns; the year groups include outmigration years 1978-1980, 1986-1988, 19982000, and 2012-2014. These year groups were chosen because they align with progressively lower return rates (Fig. 2) and span contrasting ocean temperature regimes - a period of relatively lower sea surface temperatures in the study region aligning with the 1987-1980 and 1986-1988 year groups and relatively higher sea surface temperatures associated with the 1998-2000 and 2012-2014 year groups. For each year, approximately 50 scale samples were chosen for both the 1SW and 2SW maturity groups using a stratified random sampling design (Table 1). Selection was stratified by return month (May-October) to account for within-year variability. Because most individuals returning to the Penobscot River are of hatchery origin, "naturally reared" individuals originating from wild spawning or fry stocking were excluded from this analysis. Scales were impressed on acetate slides and examined on a compound microscope at $20 \times$ magnification. Scale images were captured by an Olympus DP73 microscope camera at high resolution $(4800 \times 3600$ pixels $)$ with CellSens Entry and calibrated at 1.9 um per pixel. One representative scale from each fish was measured along a singular transect aligned on the longest axis from the scale focus to the scale edge using Image Pro Plus 7 (Media Cybernetics). Scale circuli were identified using 
Table 1. Sample sizes by smolt age for $1 \mathrm{SW}$ and 2SW Penobscot River Atlantic salmon scales for the four outmigration year groups: 1978-1980, 1986-1988, 1998-2000, and 2012-2014.

\begin{tabular}{|c|c|c|c|c|c|c|c|c|}
\hline \multirow[b]{2}{*}{ Outmigration year } & \multicolumn{4}{|l|}{$1 S W$} & \multicolumn{4}{|l|}{$2 \mathrm{SW}$} \\
\hline & Age-1 & Age-2 & Age-3 & Total & Age-1 & Age-2 & Age-3 & Total \\
\hline 1978 & 9 & 25 & 5 & 39 & 23 & 27 & 0 & 50 \\
\hline 1979 & 24 & 19 & 1 & 44 & 11 & 38 & 1 & 50 \\
\hline 1980 & 28 & 19 & 1 & 48 & 22 & 7 & 0 & 29 \\
\hline 1986 & 31 & 15 & 2 & 48 & 47 & 11 & 2 & 60 \\
\hline 1987 & 24 & 27 & 1 & 52 & 37 & 9 & 0 & 46 \\
\hline 1988 & 29 & 15 & 0 & 44 & 26 & 18 & 0 & 44 \\
\hline 1998 & 48 & 0 & 0 & 48 & 47 & 1 & 0 & 48 \\
\hline 1999 & 48 & 1 & 1 & 50 & 48 & 0 & 0 & 48 \\
\hline 2000 & 49 & 0 & 0 & 49 & 47 & 3 & 0 & 50 \\
\hline 2012 & 46 & 2 & 0 & 48 & 57 & 1 & 1 & 59 \\
\hline 2013 & 55 & 1 & 0 & 56 & 64 & 0 & 0 & 64 \\
\hline 2014 & 57 & 0 & 0 & 57 & 67 & 0 & 0 & 67 \\
\hline
\end{tabular}

Fig. 3. Image of a scale taken from 2SW Atlantic salmon with labelled growth markers.

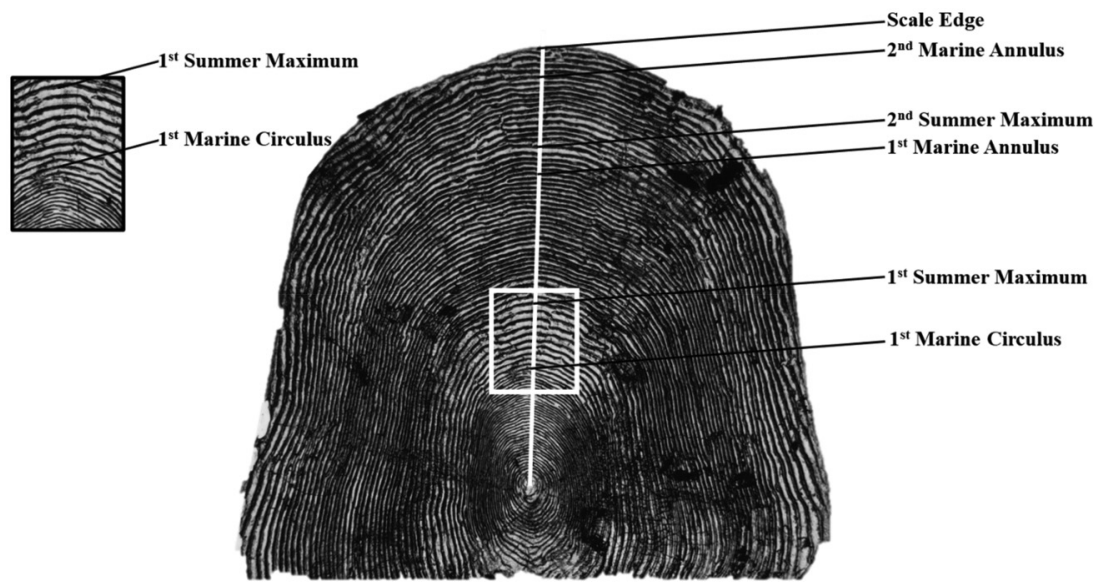

standardized protocols, and distances from the focus to various scale features were calculated (ICES 2011; Fig. 3).

Penobscot River hatchery return rates have been used as a proxy for marine survival. These rates have historically been calculated as the number of smolts stocked divided by the number of smolt origin adult returns; however, this approach attributes losses in fresh water to losses in the marine environment. To estimate a true marine return rate for the Penobscot River, Stevens et al. (2019) developed a spatially explicit model to partition annual estimates of freshwater mortality from marine mortality, thereby presenting an estimated "true" marine return rate for smolt years 1970 to 2012. The methods reported in Stevens et al. (2019) were applied to estimate marine return rates for each maturity group (i.e., 1SW and 2SW) through smolt year 2018.

\section{Growth marker definitions}

Growth marker measurements and increments were based on previously agreed-upon definitions (ICES 2011; Fig. 4). The first marine circulus (FMC) marks the river to marine habitat transition as the first of a series of wider intercirculi spacings that represent sea entry. The first summer maximum (FSM), the circulus following the maximum intercirculi spacing, represents the point of maximum growth and delineates the end of the first summer growth increment. The first summer increment represents the total growth starting from the FMC and ending at the FSM. The next marker of interest is the first marine annulus (M1); an annulus is a series of tightly spaced circuli with M1 marked as the last circulus of the series. The first winter increment, a period of decreasing intercirculi spacings, is the sum of all intercirculi spacings between the FSM and M1. The post-smolt increment is the sum of all intercirculi spacings between the FMC and M1.

After the first marine annulus, intercirculi spacings begin to widen. Similar to the FSM, the second summer maximum (SSM) is the circulus following the maximum intercirculi spacing that occurs after M1. The SSM represents the maximum growth rate during the second year at sea. The second summer increment is defined as the growth increment measured from M1 to SSM. The second winter increment is the sum of all intercirculi spacings between the SSM and the second marine annulus (M2). M2 is the second band consisting of small intercirculi spacings that appears toward the scale edge. Following M2, there can be an additional series of circuli before the scale edge that are referred to as "plus growth". During the scale auditing process, it was found that many of the 2SW fish in the 2012-2014 year group had what appeared to be an incomplete second marine annulus, in that they lacked features typically associated with an annulus (no crossing over of circuli and no clear change in circuli spacing from narrow to wide; ICES 2011). Crossover is a characteristic of annulus formation where circuli cut across previously formed circuli. Due to the fact that M2 had yet to form for $~ 59 \%$ of the fish in the 2012-2014 year group, we broadened our definition of the second winter increment to be the sum of all intercirculi spacings between the SSM and the scale edge. The second-year increment is the sum of all intercirculi spacings between M1 and the scale 
Fig. 4. Example of growth increments defined based on growth markers for a Penobscot River Atlantic salmon scale. Growth markers of interest are indicated by dots at appropriate intercirculus spacings along the scale pattern.

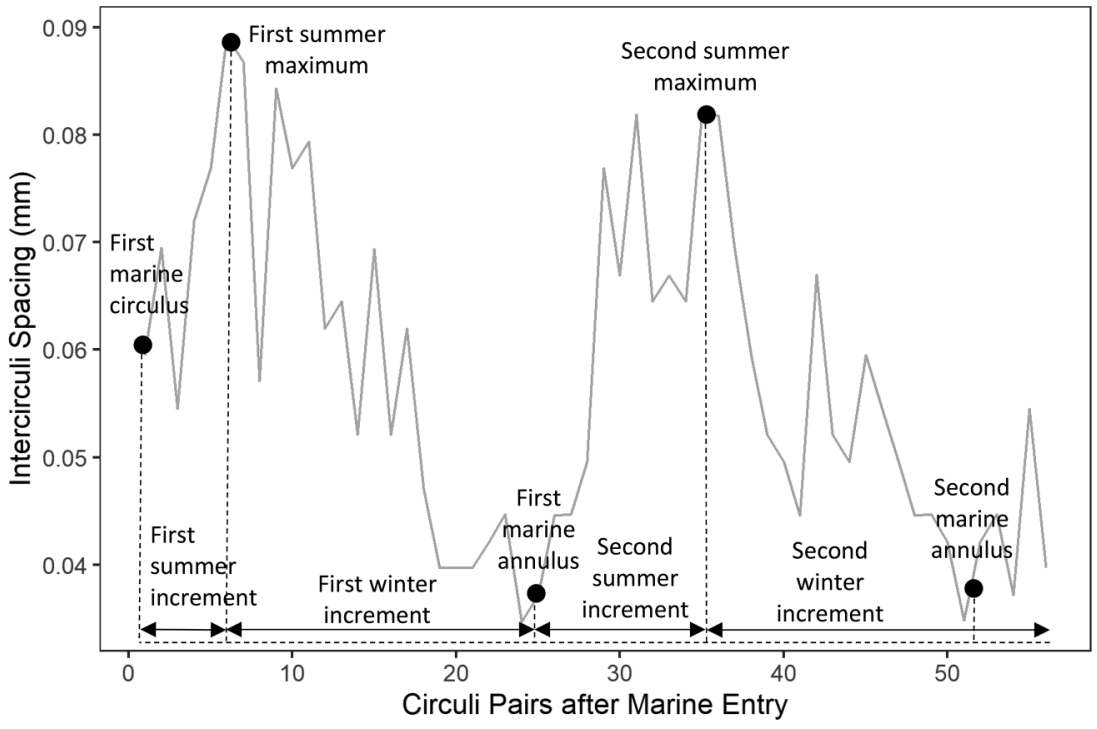

edge. The marine increment for both $1 \mathrm{SW}$ and $2 \mathrm{SW}$ fish represents all growth that occurred from marine entry (i.e., FMC) through the scale edge.

\section{Statistical analyses}

\section{Seasonal growth increment comparisons across year groups}

Differences in seasonal growth increments were investigated by one-way ANOVA among year groups for each maturity group. Seasonal growth increments in the analyses included: first summer, first winter, post-smolt, second summer (2SW only), second winter (2SW only), second year (2SW only), and total marine increments. Explanatory variables in the ANOVAs were the year groups (i.e., 1978-1980, 1986-1988, 1998-2000, 2012-2014). Differences were deemed significant at $p<0.05$. For significant ANOVAs, post hoc pairwise comparisons between year groups were conducted using Tukey's honest significant difference (HSD) test. In addition, we pooled all year groups together and compared first summer, first winter, and post-smolt increments between maturity groups via Welch's $t$ test.

\section{Growth increment and return rate correlations}

To test for evidence of compensatory growth between seasonal growth increments on the scales, we used Pearson product-moment correlation. The 1SW correlate set included the first summer and first winter increments. The $2 \mathrm{SW}$ correlate set included the first and second summer and winter increments, as well as a comparison between the post-smolt and second-year increments. We also used Pearson product-moment correlation tests to determine the strength of correlation between the seasonal growth increments and Penobscot River Atlantic salmon annual return rates. For evaluating statistical significance of the return rate tests, the degrees of freedom were adjusted for autocorrelation (Pyper and Peterman 1998).

\section{Principal component analysis}

To investigate the overall changes in growth patterns in the marine stage of Atlantic salmon, we compared seasonal growth increments for $2 \mathrm{SW}$ fish using principal component analysis. We considered individual years rather than year groups and included the first and second summer and winter increments as input variables. Correlation analysis was performed to assess relationships between the first and second principal components and the annual return rates, with degrees of freedom adjusted for autocorrelation (Pyper and Peterman 1998) when evaluating statistical significance. All analyses were performed using the software environment $R$ version 3.6.2 (R Core Team 2020).

\section{Results}

\section{Seasonal growth increment comparisons across year groups}

\section{First summer increment}

Size difference in the first summer increment across year groups was found to be statistically significant as indicated in the overall ANOVA for 1SW fish (ANOVA: $\mathrm{df}=579, \mathrm{~F}=3.102, p<0.05$; Supplementary Table S1 ${ }^{1}$; Fig. 5); however, no pairwise significant differences were detected from the post hoc Tukey multiple pairwise comparisons. For $2 \mathrm{SW}$ fish, a statistically significant difference was not detected among year groups in the size of the first summer increment (ANOVA: $\mathrm{df}=611, \mathrm{~F}=0.550, p>0.05$; Supplementary Table $S 2^{1}$; Fig. 5).

\section{First winter increment}

A statistical difference among year groups of 1SW fish in the size of the first winter increment was indicated (ANOVA: $\mathrm{df}=579$, $F=5.587, p<0.01$; Supplementary Table S1 ${ }^{1}$; Fig. 5). Post hoc Tukey multiple pairwise comparisons show that the 1998-2000 year group's first winter increment growth was 13.5\% larger than the 1986-1988 $(p<0.01)$ and $12.6 \%$ larger than the 2012-2014 $(p<0.01)$ year groups, with the 1978-1980 year group showing intermediate growth.

Similarly, 2SW fish showed a statistically significant difference in the first winter increment among year groups (ANOVA: $\mathrm{df}=611$, $F=17.926, p<0.001$; Supplementary Table S2 ${ }^{1}$; Fig. 5). Post hoc pairwise comparisons revealed that, like the $1 \mathrm{SW}$ fish, the first winter increment for the 1998-2000 year group was largest. On average, it was $20.0 \%$ larger than the 1978-1980 year group ( $p<0.001$ ), $23.1 \%$ larger than the 1986-1988 year group ( $p<0.001)$, and 19.1\% larger than the 2012-2014 year group $(p<0.001)$. 
Fig. 5. Growth increments by outmigration year group (1SW: first row, 2SW: second and third rows). Within each growth increment, year groups without a common letter differ $(p<0.05)$ based on post hoc Tukey multiple-pairwise comparisons.
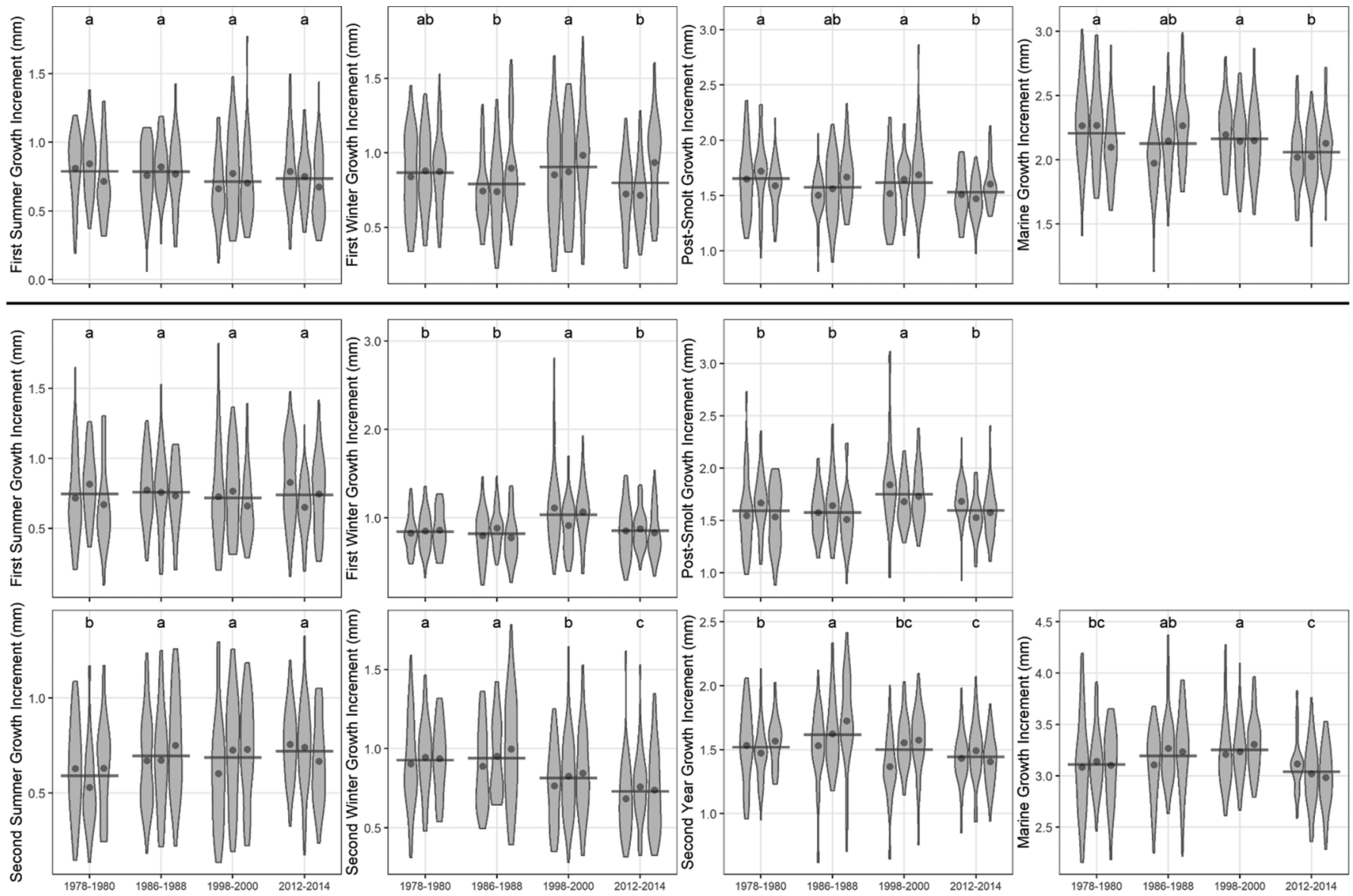

\section{Post-smolt increment}

A statistically significant difference was detected for $1 S W$ fish when comparing the post-smolt increment among year groups (ANOVA: df $=579, \mathrm{~F}=6.142, p<0.001$; Supplementary Table $\mathrm{S} 1^{1}$; Fig. 5). The post-smolt increment for the 2012-2014 year group was significantly smaller than the 1978-1980 and 1998-2000 year groups by $7.7 \%(p<0.001)$ and $5.6 \%(p<0.05)$, respectively. The $1986-$ 1988 year group demonstrated intermediate post-smolt growth.

Significant differences were also detected in the post-smolt increment among $2 \mathrm{SW}$ fish year groups (ANOVA: $\mathrm{df}=611, \mathrm{~F}=13.411$, $p<0.001$; Supplementary Table S2 ${ }^{1}$; Fig. 5). Similar to the first winter increment comparisons among 2SW fish, the post-smolt increment for the 1998-2000 year group was large. The postsmolt growth increment for the 1998-2000 year group was $9.4 \%-$ 10.5\% larger than that for the 1978-1980, 1986-1988 and 2012-2014 year groups $(p<0.001)$.

\section{Second summer increment}

A significant difference was detected in the second summer increment among year groups of 2SW fish (ANOVA: $\mathrm{df}=611, F=7.456$, $p<0.001$; Supplementary Table S2 ${ }^{1}$; Fig. 5). Post hoc pairwise comparisons show that the second summer increments for the 19861988, 1998-2000, and 2012-2014 year groups were all larger than that for the 1978-1980 year group by $16.2 \%(p<0.01), 15.0 \%(p<0.01)$, and $19.6 \%(p<0.001)$, respectively.

\section{Second winter increment}

The overall ANOVA indicated a significant difference in the size of the second winter increment among year groups of 2SW fish (ANOVA: $\mathrm{df}=611, \mathrm{~F}=25.153, p<0.001$; Supplementary Table $\mathrm{S}^{1}$; Fig. 5). The second winter increment for the 1998-2000 year group was $13.1 \%$ and $14.4 \%$ smaller than that for the $1978-1980$ $(p<0.01)$ and 1986-1988 $(p<0.001)$ year groups, respectively, while the 2012-2014 year group was smaller than the 1998-2000 year group by $10.8 \%(p<0.05)$ and smaller than both of the 19781980 and $1986-1988$ year groups by $23.9 \%$ and $25.2 \%$, respectively $(p<0.001)$. Pairwise comparisons showed no difference in the second winter increment between the 1978-1980 and 1986-1988 year groups.

\section{Second-year increment}

The size of the second-year increment was statistically significantly different among 2SW year groups (ANOVA: $\mathrm{df}=611, \mathrm{~F}=$ 13.060, $p<0.001$; Supplementary Table S2 ${ }^{1}$; Fig. 5). The secondyear increment for the 2012-2014 year group was 5.1\% and $11.3 \%$ smaller than that for the 1978-1980 $(p<0.05)$ and 1986-1988 year groups $(p<0.001)$, respectively. The 1998-2000 year group showed intermediate scale growth within the second-year increment and was on average $7.4 \%$ smaller than the 1986-1988 year group ( $p<0.001)$. The $1986-1988$ year group was $6.2 \%$ larger than the 1978-1980 year group $(p<0.01)$.

\section{Marine increment}

The full marine growth increment showed a statistically significant difference for year groups of 1 SW fish (ANOVA: $\mathrm{df}=579$, $F=7.574, p<0.001$; Supplementary Table S1 ${ }^{1}$; Fig. 5). The marine increment for the 2012-2014 year group was significantly smaller 
Fig. 6. Successive seasonal growth increment Pearson product-moment correlation plots (1SW: first row, 2SW: second and third rows). Correlation values located at the top right and lines indicate year group specific correlations.
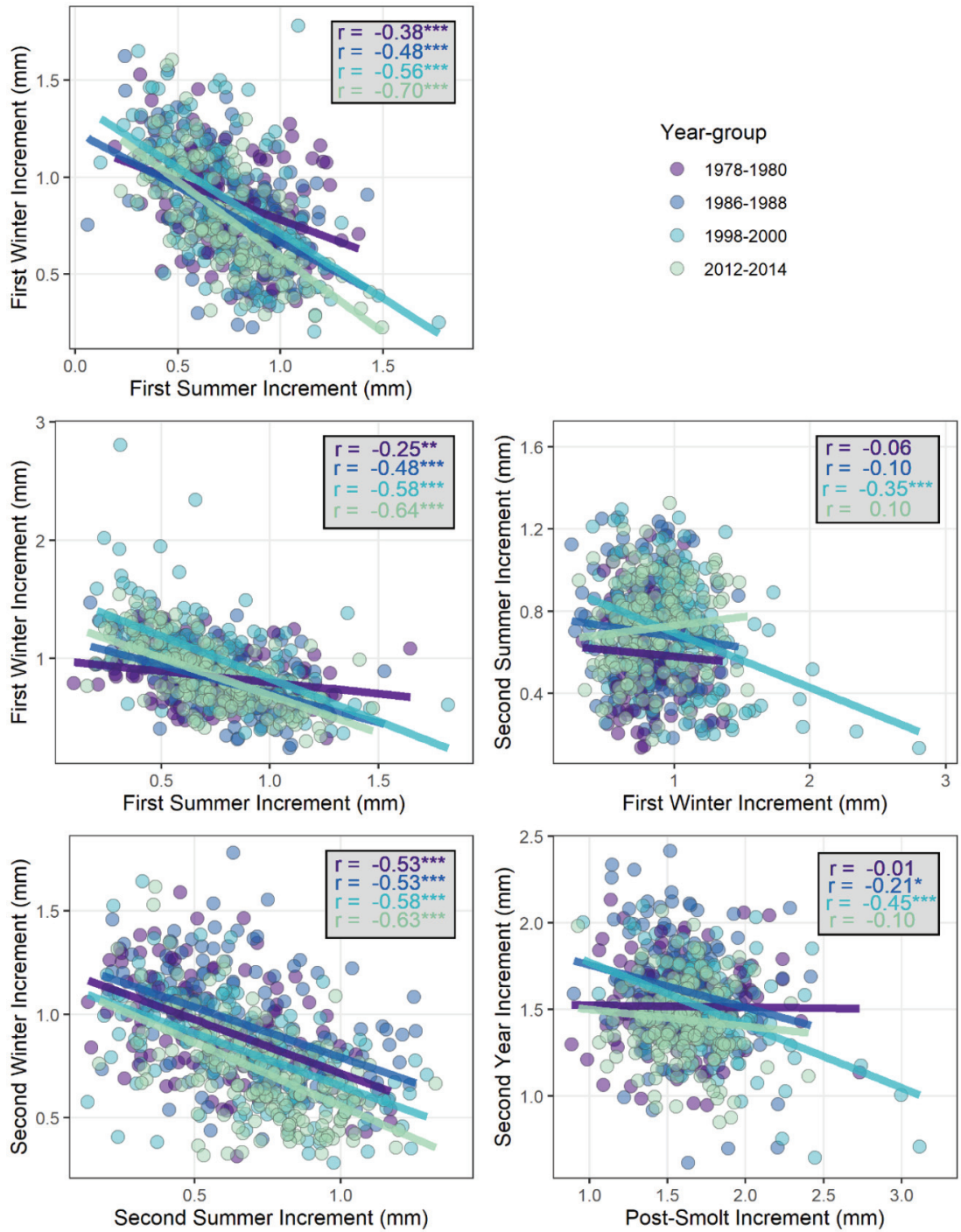

than that for the 1978-1980 year group by $6.8 \%(p<0.001)$ and the $1998-2000$ year group by $4.9 \%(p<0.01)$.

We also detected significant differences in the marine growth increment among year groups of 2SW fish (ANOVA: $\mathrm{df}=611, \mathrm{~F}=13.097$, $p<0.001$; Supplementary Table S2 ${ }^{1}$; Fig. 5). Pairwise comparisons showed that the marine growth increment was smallest in the 2012-2014 year group, with the 1986-1988 year group showing a larger increment by $5.0 \%(p<0.001)$ and the $1998-2000$ year group appearing 6.8\% larger $(p<0.001)$. The $1978-1980$ year group marine increment was not significantly larger than that for the 2012-2014 year group or smaller than that for the 1986-1988 year group, but it was significantly smaller than the 1998-2000 year group's average marine increment by $4.5 \%(p<0.01)$.

\section{Growth increment differences between maturity groups}

Between maturity groups, there was no statistical difference in the first summer increment, but there were differences detected in the first winter increment and in the post-smolt increment. In both cases, 2SW salmon had larger increments than 1SW salmon. On average, the first winter increment and the post-smolt increment for 2SW salmon was larger than $1 \mathrm{SW}$ salmon by $5.6 \%(t=-2.887$, $p<0.01)$ and $2.5 \%(t=-2.212, p<0.05)$, respectively.

\section{Growth increment correlations}

For 1SW fish, we evaluated the strength of correlation between the first summer increment and the first winter increment (Fig. 6). The first summer increment was negatively correlated with the first winter increment $(r=-0.54, p<0.001)$, suggesting that summer and winter growth increments, as defined in our study, are compensatory. When examining the year group specific correlations, the strength of correlation increased from -0.38 in the 1978-1980 year group $(p<0.001)$ to -0.48 and -0.56 in the $1986-1988$ and 19982000 year groups, respectively $(p<0.001)$, and then to -0.70 in the 2012-2014 year group $(p<0.001)$, indicating an increasing compensatory relationship between seasons during the post-smolt phase across the four year groups (Supplementary Table S3 ${ }^{1}$ ).

For $2 \mathrm{SW}$ fish, we conducted correlation tests between the first summer, first winter, second summer, second winter, and the post-smolt and second-year increments. Like 1SW fish, there was a negative correlation between the first summer and first winter increments $(r=-0.52, p<0.001)$. Also, like $1 S W$ fish, the year group specific correlations increased in strength from -0.25 in the 1978-1980 year group $(p<0.01)$ to -0.48 and -0.58 in the 19861988 and 1998-2000 year groups $(p<0.001)$ and to -0.64 in the 2012-2014 year group $(p<0.001)$. The first winter increment was 
Fig. 7. (A) Biplot of first and second principal components from analysis of $2 \mathrm{SW}$ seasonal growth increments. Darker line shading indicates stronger relative influence among growth increments. (B) Correlation plot of the first principal component and return rate for 2SW Atlantic salmon $(r=0.77, p<0.05)$. [Colour online.]

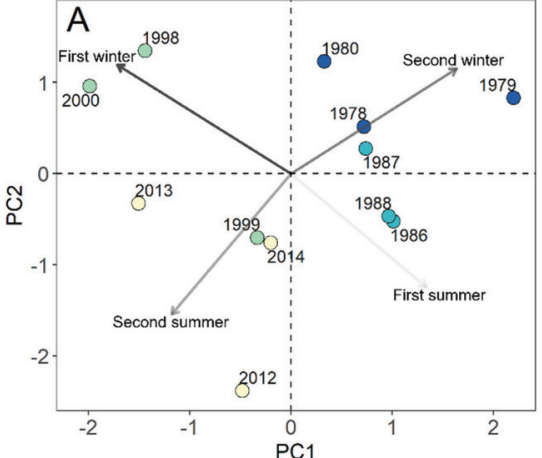

Table 2. Pearson product-moment correlations ( $r$ ) for 1SW and 2SW growth increments with annual return rates.

\begin{tabular}{lllllr}
\hline & \multicolumn{2}{l}{ 1SW } & & \multicolumn{2}{l}{ 2SW } \\
\cline { 2 - 3 } Growth increment & df & $r$ & & df & \multicolumn{1}{l}{$r$} \\
\hline First summer & 15.6 & 0.54 & 41.9 & 0.09 \\
First winter & 21.8 & 0.08 & & 10.2 & -0.44 \\
Post-smolt & 17.7 & 0.46 & & 11.4 & -0.41 \\
Second summer & - & - & $\mathbf{7 . 8}$ & $-\mathbf{0 . 6 0}$ \\
Second winter & - & - & $\mathbf{6 . 5}$ & $\mathbf{0 . 7 3}$ \\
Second year & - & - & 10.0 & 0.32 \\
Marine & 11.9 & 0.44 & 7.4 & -0.09 \\
\hline
\end{tabular}

Note: Degrees of freedom are corrected for autocorrelation. Correlations in bold indicate significance at $p<0.05$.

slightly negatively correlated to the second summer increment $(r=-0.12, p<0.01)$; however, year-specific correlations were nonsignificant for three out of the four groups and the direction of correlation was mixed, suggesting a weak relationship between the first winter and second summer. The 1998-2000 year group showed the strongest negative correlation between first winter and second summer increments. This correlation was statistically significant $(r=-0.35, p<0.001)$, but upon inspection, the relationship was largely driven by a small number of scales with abnormally large winter increments. The second summer increment was negatively correlated with the second winter increment $(r=-0.52, p<0.001)$. The year group specific correlations were of similar strength to the overall correlation, suggesting little temporal change in the compensatory relationship between the second summer and second winter increments across year groups. Lastly, a slight negative correlation was found between the post-smolt and second-year increments $(r=-0.20, p<0.001)$. The correlation between post-smolt and second-year increments could largely be attributed by the 1986-1988 and 1998-2000 year group specific correlations $(r=-0.21, p<0.05$ and $r=-0.45, p<0.001$, respectively), whereas no significant correlations were detected in other year groups when analyzed separately.

\section{Return rate correlations}

Seasonal growth increment and return rate correlations were not statistically significant for 1SW fish (Table 2). For 2SW fish, the second summer increment was significantly negatively correlated to return rates ( $\mathrm{df}=7.8, r=-0.60, p<0.05$ ), and the second winter increment was significantly positively correlated to return rates (df $=6.5, r=0.73, p<0.05$; Table 2 ); however, there was no significant correlation between return rate and the second-year increment, which is the second summer and second winter increments combined.

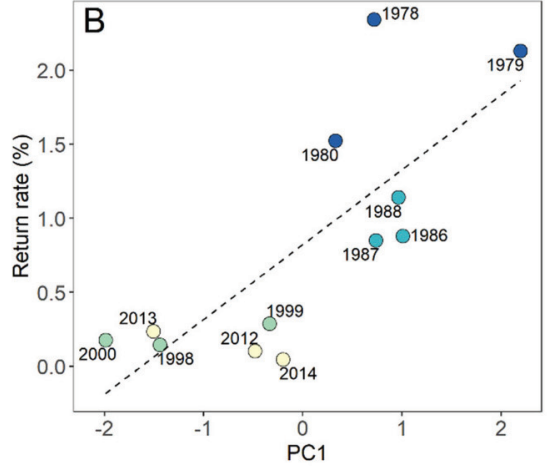

Principal component analysis

For 2SW fish, the first and second principal components explained $66.5 \%$ of the variance in the yearly averaged seasonal growth increments, with $37.8 \%$ in PC1 and $28.7 \%$ in PC2 (Fig. 7). Larger second winter increments characterize the early years (i.e., 1978-1980, 1986-1988) with scores $>0$ on PC1, while larger first winter and second summer increments characterize the later years (i.e., 1998$2000,2012-2014)$ with scores $<0$ on the PC1 axis. Loadings for summer and winter scale growth increments were positioned on diagonally opposing quadrants from the plot origin, suggesting negative correlations between the seasonal increments, a pattern that supports the seasonal compensatory relationships that were detected in the sequential growth increment correlations (Supplementary Table $S 3^{1}$ ). Annual scores on the first principal component were significantly positively correlated to return rates $(\mathrm{df}=5.5$, $r=0.77, p<0.01$; Fig. 7), such that larger second winter growth is associated with higher return rates, which is similar to the positive univariate correlation result between the second winter increment and return rates. There was no significant correlation between annual scores on the second principal component and return rates $(p>0.05)$.

\section{Discussion}

Our objective was to examine changes in marine growth patterns of Penobscot River Atlantic salmon and investigate whether these changes were related to observed declines in marine survival. In contrast to previous studies that have focused on growth through the post-smolt stage, we considered growth over the full course of the marine life stage - from ocean entry to return migration back to natal rivers. This analysis of the complete marine growth period revealed limited changes during the first year at sea but substantial changes in the second year, and these second-year growth changes were related to return rate trends.

We did not discern any change in growth during the initial months at sea for either 1SW or 2SW fish. This finding indicates that the growth experience through the first summer has remained stable - at least for the fish that survive to return to the Penobscot even though hatchery practices and ocean conditions have varied during the years spanned by this study (Mills et al. 2013b; Maynard and Trial 2014; USASAC 2020). The stability of growth during the first summer at sea may indicate that Atlantic salmon need to achieve a certain amount of growth during their first months at sea to survive the early marine life stage. That $1 \mathrm{SW}$ and $2 \mathrm{SW}$ growth patterns are similar during these early months suggests that Atlantic salmon with distinct life history strategies are not initially experiencing differential growth when they enter the 
ocean and that perhaps there are dynamics occurring after the post-smolt phase that are contributing to declines of 2SW salmon.

Indeed, dissimilar growth patterns appear by the end of the first year at sea. The combined first summer and winter growth patterns resulted in 1SW salmon in the 2012-2014 year group experiencing the least post-smolt growth. First-year growth patterns for 2SW fish did not show this decline in 2012-2014, but instead demonstrated higher post-smolt growth during 19982000. The divergence in $1 \mathrm{SW}$ and $2 \mathrm{SW}$ growth patterns during the latter portion of the post-smolt stage suggests that different life history strategies may be reflected biologically within the first winter at sea or that salmon with distinct life history strategies may be using the marine environment in different ways, perhaps becoming spatially separated during the post-smolt stage. This pattern could also be explained by high levels of selection following the first sea winter, such that only the fastestgrowing post-smolt stage $2 \mathrm{SW}$ fish survive their time at sea.

The most substantial changes in growth observed in this study occurred in $2 \mathrm{SW}$ fish during their second year at sea. Second summer growth increased significantly for year groups after 1978-1980, with later year groups experiencing 15\%-20\% more growth during this seasonal increment. Higher growth during the second summer was also detected after the 1980s for 2SW fish sampled from the North American Atlantic salmon population complex, indicating the effect may have emerged around a similar time among regional Atlantic salmon populations (Tillotson et al. 2021). Even greater changes occurred during the second winter increment. The year groups that outmigrated after 1990 showed progressive declines in second winter growth, such that the 2012-2014 year group experienced $\sim 25 \%$ less growth during this seasonal increment than the pre-1990 year groups. The arrested growth during the second year at sea provides new insights to guide investigations into factors that may be shaping Atlantic salmon productivity following the 1990s ecosystem shift. Since that time, Penobscot River Atlantic salmon that survived the marine life stage appear to have been more dependent on high growth rates during the second summer period to offset reduced growth during the final winter at sea. Whether the arrested growth during the final winter is related to marine residence time is yet to be determined.

In addition to seasonal growth changes, our analyses demonstrate strong seasonal compensation in growth during the marine stage. We found evidence of a compensatory relationship between successive summer and winter growth increments in both the first and second years at sea. Compensatory growth is observed in many fish species, including Atlantic salmon (Nicieza and Metcalfe 1997; Hogan and Friedland 2010), as a way of buffering food limitations or other factors that lead to poor growth during one period by compensating during another period. We demonstrated strong compensatory growth between seasons within a year, which has also been supported by analyses of other North American Atlantic salmon populations (Friedland et al. 2009b; Tillotson et al. 2021). Throughout our analysis, we detected general increases of $59 \%$ and $88 \%$ in the strength of the summerwinter compensatory relationship during the post-smolt phase in both $1 S W$ and $2 S W$ maturity groups, respectively. Although the change in correlation strength over time is smaller (17\%), a similar pattern of strengthening summer-winter compensation is shown by $2 \mathrm{SW}$ fish in the second year. As such for both cohorts, fish that grew less during the summer demonstrated stronger growth during winter of that sea-year and vice versa. Since our sample only represents fish that survived the marine life stage and returned to the Penobscot River, these results indicate that surviving Atlantic salmon may increasingly require sufficient adaptive capacity for growth compensation across portions of their time at sea. In particular, they appear to be increasingly dependent on compensatory growth at a time when winter growth during the second year at sea is declining. Our results indicate that with lower second winter growth in recent years (i.e., 2012-2014), seasonal compensatory growth is no longer sufficient to avoid a reduction in second-year or overall marine growth.

Return rates of 2 SW Atlantic salmon show a decreasing trend over time; in the 1978-1980 and 1986-1988 year groups, $\sim 0.8 \%-$ $2.3 \%$ of salmon stocked exiting the Penobscot River returned from their ocean migration, whereas for the more recent 19982000 and $2012-2014$ year groups, only $0.05 \%-0.3 \%$ managed to successfully complete the migration (Stevens et al. 2019). There has not been a similar trend for 1SW salmon, as return rates for this maturity group have remained at low levels of around $0.02 \%-0.6 \%$ over the time series (Fig. 2). With return rates as critically low as they have been for 1SW fish and now for 2SW fish, the few salmon that successfully return to the Penobscot River represent unique growth patterns and fitness traits.

Similar to other studies of North American Atlantic salmon stocks, we did not detect a return rate dependence on post-smolt scale growth (Friedland and Haas 1996; Friedland et al. 2005, 2009b; Hogan and Friedland 2010). Hogan and Friedland (2010) reported an increase in post-smolt growth during the 1990s while returns decreased, suggesting growth-independent post-smolt survival. We also found stronger post-smolt growth in 1SW and 2SW salmon that outmigrated during 1998-2000, concurrent with a decline in return rates for $2 \mathrm{SW}$ salmon. However, this relationship did not persist through the 2012-2014 year group, when post-smolt growth returned to lower levels. Friedland et al. (2012) suggested that predation pressure, rather than growth, is controlling post-smolt recruitment of North American stocks. Size selectivity is expected to influence predation rates, given that slow-growing fish remain in more vulnerable size classes for longer than fast-growing fish (Miller et al. 2014). If size-selective predation were occurring during the post-smolt phase to the extent that only fast-growing fish survived, we would expect larger post-smolt growth increments in the later year groups. While this was the case for the 1998-2000 cohort, post-smolt growth during the 2012-2014 year group was smaller again; as such, evidence that size-selective predation during the postsmolt stage mediates survival is equivocal in this study. While predation, be it size-selective or not, is occurring during the early post-smolt phase, there are likely additional pressures exerted over the full marine life stage that affect return rates of Atlantic salmon to the Penobscot River.

Alternatively, our analyses indicated that growth beyond the post-smolt stage may more strongly influence return rates. We found significant changes in second-year growth increments (Supplementary Table $S 2^{1}$ ) and strong correlations with return rates (Table 2). Similar to our findings, Izzo and Zydlewski (2017) examined second-year growth of Atlantic salmon from other Maine rivers and found evidence to suggest that the early spring of the second year at sea could be playing a role in the decline of 2SW salmon. Tillotson et al. (2021) found that survival through the marine life stage in recent years versus prior to 1990 appears to require more growth during the second summer at sea, when Atlantic salmon from across North America feed in the waters off West Greenland. However, reported declines in high-quality prey for Atlantic salmon since the 1990s ecosystem shift may be constraining growth opportunities during the summer feeding period (Renkawitz et al. 2015). These constraints may be exacerbated by higher metabolic demands due to warmer ocean temperatures during most of the post-1990 period. Together, these results suggest that Penobscot River Atlantic salmon that survive the marine life stage may now be limited to those that can find adequate prey to support higher summer growth under post-1990 feeding conditions.

In addition to the inverse relationship between second summer growth and return rates, our results showed a decline in second winter growth as return rates decreased. This pattern indicates that second winter growth may impose another key constraint on marine survival as maturing salmon undertake their return 
migration. The second winter growth observed in recent years may represent minimum growth thresholds required for survivors of the homeward journey to the Penobscot River. It may also reflect changes in salmon and ocean phenology, with Atlantic salmon returning earlier to the Penobscot River (Juanes et al. 2004; Staudinger et al. 2019), and ocean warming and cooling patterns altering the lengths of the summer- and winter-like seasons in a portion of the marine range of Atlantic salmon (Thomas et al. 2017). These changes may create conditions under which Atlantic salmon have shorter periods of time at sea to grow and build energy reserves needed for migration and reproduction.

For an Atlantic salmon population with severely low return rates, the changes in survivor growth patterns we detected may represent adaptive strategies necessary to return from the marine phase. As such, high fitness may not mean fast or steady growth but rather an increased capacity for compensatory growth during the middle portion of the marine phase, such as during the latter portion of the post-smolt stage and (or) through the second summer at sea. Critical transitions during seaward migration have often been cited as exerting substantial controls on marine survival (Thorstad et al. 2012), but seasonal growth changes we identified as most strongly related to marine survival occur when salmon are at sea between migratory transitions. These results indicate that marine growth may be a key determinant of marine survival of Penobscot River Atlantic salmon. Developing a better scientific understanding of the factors that control marine growth, particularly during the seasons identified herein, will help improve evaluations of recovery potential and risk for this stock.

\section{Limitations}

This study documents seasonal growth changes in Atlantic salmon during their marine life stage and identifies the important role that growth during the second year at sea may exert on survival. However, our analyses are constrained by several limitations. First, all studies that rely on scale samples are inherently biased, as we are only able to see the growth records of the fish that successfully survived to the stage of sampling. This survivor bias may mask the full extent of growth changes that are being experienced across the population, as fish that did not survive may have experienced changes in growth that were stronger in magnitude or that may have been more concentrated in a particular portion of their time at sea prior to sampling.

Another limitation is our incomplete understanding of the spatiotemporal details and the annual variability associated with the marine migration of Atlantic salmon. This hinders our ability to establish high-resolution relationships between scale growth and Northwest Atlantic Ocean ecosystem conditions that may help identify drivers of growth changes or when and where they are most likely to occur. Progress has been made in tracking salmon smolt outmigration to the Labrador Sea (Chaput et al. 2019) and previously spawned adult salmon within the Northwest and Northeast Atlantic (LaCroix 2013; Strøm et al. 2017; Rikardsen et al. 2021). Investigations have also been conducted to track subadult salmon migration from Greenland to natal rivers (Renkawitz et al. 2021). While there are general ideas about where Atlantic salmon are during different portions of their time at sea (Reddin 1988; Thorstad et al. 2010; Sheehan et al. 2012; Bradbury et al. 2021), these newer tracking studies are providing a level of detail previously unavailable. The continuation and evolution of tracking studies will inform the development of detailed migration models that will enable researchers to accurately map the growth signals obtained from scale studies with specific environmental conditions experienced by the populations during their marine residence.

It is also important to note that this study focuses on a hatcherysupported population of Atlantic salmon, and hatchery rearing practices may influence marine growth patterns. Fish in the 1978-1980 and 1986-1989 year groups were stocked at a wider range of smolt sizes after being raised for one to two years in the hatchery, while fish in the 1998-2000 and 2012-2014 year groups were stocked after being raised under modified hatchery practices to a narrower size range in only one year of time. Our findings that 1SW and 2SW fish in all year groups grew similarly during their first few months at sea suggest that these hatchery changes did not influence early ocean growth patterns of fish that ultimately completed the marine life stage. However, the change in stocking practices does reflect a reduction in growth diversity prior to stocking, and specific behaviors that would contribute to fast growth in the hatchery may also influence outcomes during the marine life stage. For example, conditions and behaviors associated with fast hatchery growth can produce larger smolts but may come with a diminished anti-predator response (Houde et al. 2010), which may influence relationships between growth patterns and return rates. Continually assessing rearing practices to promote resilience is important, particularly during periods of unfavorable marine survival.

Finally, this study derives new insights into growth changes of Penobscot River Atlantic salmon and marine growth-survival relationships. It is important to recognize that processes outside of our investigation may be influencing the perception of growthsurvival relationships. First, if selective forces vary over time, survival rates could change, even if growth remains consistent (Jacobson et al. 2008; Losee et al. 2014). For example, periods of time in which growth does not appear to be changing (i.e., first summer) could represent survival bottlenecks if factors controlling survival are decoupled from growth. The effects on survival we ascribe to larger second summer growth and reduced second winter growth could originate during the first summer if stronger selective forces during that period aligned with the overall marine survival pattern. Our capacity to investigate this possibility is hindered by our inability to estimate marine survival at a seasonal scale and resulting reliance on survival rates covering the full marine life stage. Second, it is possible that a greater portion of Penobscot River Atlantic salmon are maturing after one sea-winter. In this situation, 1SW survival rates that appear relatively stable over time may have actually declined substantially but have been offset by higher 1SW maturity rates. In turn, the perceived decline in 2SW survival may have been associated with more of those fish maturing earlier (Olmos et al. 2020; Tillotson et al. 2021). Separating changes in maturity rates from survival has proven difficult but is a prerequisite for better interpreting the growth-survival relationship.

\section{Summary and future directions}

Penobscot River Atlantic salmon exist near the southern extent of the range of North American salmon populations, and with warming in the Northwest Atlantic Ocean projected to continue (Saba et al. 2016; Alexander et al. 2018), we can expect broad changes across their life stages and habitat areas. The results we present in this study show a change in seasonal growth patterns around the same time that an ecosystem shift occurred that altered physical conditions, the food web, and energy flow to Atlantic salmon (Mills et al. 2013b). The strongest declines in marine growth for both 1SW and 2SW salmon occurred during the 2012-2014 year group, a period that aligned with exceptionally warm ocean temperatures in the Northwest Atlantic habitat area. Warm temperatures exert a direct influence on fish growth by increasing metabolic demands, which may be compounded by food web changes that alter the composition and quality of prey available to Atlantic salmon. Our findings indicate that growth during the second summer may be particularly important for countering reductions in second winter growth. As such, fish that survive the marine phase may be those that build sufficient reserves during their summer feeding period off West Greenland - an outcome that may have become increasingly difficult since the 1990s given changes in prey composition and energy density of salmon diets (Renkawitz et al. 2015). Together these ecosystem changes may contribute to observed relationships between 
growth patterns and declining return rates in this population. Investigating how past ecosystem conditions - particularly the changes that were experienced during the 1990s and in recent periods of exceptional ocean temperatures - are related to Atlantic salmon growth patterns would provide key insights that are necessary for anticipating how Penobscot River Atlantic salmon may be affected by climate-driven ecosystem changes in the future. Growth changes observed in this study provide a basis for formulating hypotheses and analyses for subsequent investigations of linkages among ecosystem conditions, growth, and survival.

The most substantial decline in growth we observed occurred during the late marine phase. By this point in their life history, 2SW Atlantic salmon have, for the most part, reached their adult size. In this important final phase of growth, energy is no longer allocated towards getting bigger but rather towards building up energy reserves for maturation, fecundity, and migration. Penobscot River Atlantic salmon must migrate further south than any other North American Atlantic salmon population, and as such, must spend more energy during the homeward migration, a migration that may be occurring earlier. Approximately 59\% of 2SW fish in the 2012-2014 year group returned to the Penobscot River without a fully formed second marine annulus. Growth patterns showed decreasing circuli spacings near the edge of these scales, suggesting that annulus formation was in progress, yet features associated with annulus completion such as "circulus crossover" or "plusgrowth" were absent, which could be associated with an earlier return migration. If surviving their ocean life stage now requires foregoing this last growth opportunity, the viability of the population in the long term is uncertain. Understanding bioenergetics associated with migration and maturation under changing ocean ecosystem conditions will be important for assessing individual and population implications of changes in late marine growth.

Finally, our analyses indicated that growth beyond the postsmolt stage influences marine survival, and simulation modeling could help expand our understanding of how growth may influence Atlantic salmon population recovery. With the differential return rates between 1SW and 2SW Penobscot River Atlantic salmon, it remains unclear whether a larger proportion of the population is maturing as 1SW than in the past (Olmos et al. 2019), whether maturity decisions are determined by growth patterns, and how growth and maturity schedules affect reproductive potential and population productivity (Jacobson et al. 2021). Simulation models provide a tool for exploring potential linkages among growth, maturity, and survival to gain a more holistic insight into the processes that are shaping population outcomes. Developing an understanding of linkages among ecosystem conditions, growth and other population processes, and marine survival will be foundational for evaluating risks to Atlantic salmon populations at present and into the future.

\section{Acknowledgements}

The authors acknowledge the years of work by Maine Department of Marine Resources staff to monitor and obtain scale samples from returning Atlantic salmon at the fish traps on the Penobscot River, and we appreciate their willingness to make archived scales available for the collection of growth data reported in this paper. We also thank Molly McCarthy-Cunfer, Paul Music, and Audrey Dean for their contributions to scale processing. This research was supported by funding from NOAA Fisheries' Atlantic Salmon Ecosystems Research Team administered through the Cooperative Institute for the North Atlantic Region via NOAA grant No. NA14OAR4320158.

\section{References}

Alexander, M.A., Scott, J.D., Friedland, K.D., Mills, K.E., Nye, J.A., Pershing, A.J., and Thomas, A.C. 2018. Projected sea surface temperatures over the 21st century: Changes in the mean, variability and extremes for large marine ecosystem regions of Northern Oceans. Elementa, 6: 9. doi:10.1525/elementa.191.
Barber, W.E., and Walker, R.J. 1988. Circuli spacing and annulus formation: Is there more than meets the eye? The case for sockeye salmon, Oncorhynchus nerka. J. Fish Biol. 32: 237-245. doi:10.1111/j.1095-8649.1988.tb05357.x.

Beaugrand, G., and Reid, P.C. 2003. Long-term changes in phytoplankton, zooplankton and salmon related to climate. Global Change Biol. 9(6): 801-817. doi:10.1046/j.1365-2486.2003.00632.x.

Beaugrand, G., and Reid, P.C. 2012. Relationships between North Atlantic salmon, plankton, and hydroclimatic change in the Northeast Atlantic. ICES J. Mar. Sci. 69(9): 1549-1562. doi:10.1093/icesjms/fss153.

Borggaard, D.L., Dick, D.M., Star, J., Alexander, M., Bernier, M., Collins, M., et al. 2019. Atlantic salmon (Salmo salar) scenario planning pilot report. Greater Atlantic Region Policy Series, 19(05). NOAA Fisheries Greater Atlantic Regional Fisheries Office. Available from www.greateratlantic.fisheries.noaa. gov/policyseries.

Bradbury, I.R., Lehnert, S.J., Messmer, A., Duffy, S.J., Verspoor, E., Kess, T., et al. 2021. Range-wide genetic assignment confirms long-distance oceanic migration in Atlantic salmon over half a century. ICES J. Mar. Sci. 78: 1434-1443. doi:10.1093/icesjms/fsaa152.

Chaput, G., Carr, J., Daniels, J., Tinker, S., Jonsen, I., and Whoriskey, F. 2019. Atlantic salmon (Salmo salar) smolt and early post-smolt migration and survival inferred from multi-year and multi-stock acoustic telemetry studies in the Gulf of St. Lawrence, northwest Atlantic. ICES J. Mar. Sci. 76(4): 1107-1121. doi:10.1093/icesjms/fsy156.

Doyle, R.W., Talbot, A.J., and Nicholas, R.R. 1987. Statistical interrelation of length, growth, and scale circulus spacing: Appraisal of a growth rate estimator for fish. Can. J. Fish. Aquat. Sci. 44(9): 1520-1528. doi:10.1139/f87-183.

Fay, C., Bartron, M., Craig, S., Hecht, A., Pruden, J., Saunders, R., et al. 2006. Status Review for Anadromous Atlantic Salmon (Salmo salar) in the United States. Report to the National Marine Fisheries Service and U.S. Fish and Wildlife Service. Available from http://www.nmfs.noaa.gov/pr/species/ statusreviews.htm.

Fisher, J.P., and Pearcy, W.G. 1990. Spacing of scale circuli versus growth rate in young coho salmon. Fish. Bull. 88: 637-643.

Friedland, K.D., and Haas, R.E. 1996. Marine post-smolt growth and age at maturity of Atlantic salmon. J. Fish Biol. 48: 1-15. doi:10.1111/j.1095-8649.1996. tb01414.x.

Friedland, K.D., Haas, R.E., and Sheehan, T.F. 1996. Post-smolt growth, maturation, and survival of two stocks of Atlantic salmon. Fish. Bull. 94: 654663.

Friedland, K.D., Hansen, L.P., Dunkley, D.A., and MacLean, J.C. 2000. Linkage between ocean climate, post-smolt growth, and survival of Atlantic salmon (Salmo salar L.) in the North Sea area. ICES J. Mar. Sci. 57: 419-429. doi:10.1006/jmsc.1999.0639.

Friedland, K.D., Chaput, G., and MacLean, J.C. 2005. The emerging role of climate in post-smolt growth of Atlantic salmon. ICES J. Mar. Sci. 62(7): 1338-1349. doi:10.1016/j.icesjms.2005.04.013.

Friedland, K.D., MacLean, J.C., Hansen, L.P., Peyronnet, A.J., Karlsson, L., Reddin, D.G., et al. 2009a. The recruitment of Atlantic salmon in Europe. ICES J. Mar. Sci. 66: 289-304. doi:10.1093/icesjms/fsn210.

Friedland, K.D., Moore, D., and Hogan, F. 2009b. Retrospective growth analysis of Atlantic salmon (Salmo salar) from the Miramichi River. Can. J. Fish. Aquat. Sci. 66(8): 1294-1308. doi:10.1139/F09-077.

Friedland, K.D., Manning, J.P., Link, J.S., Gilbert, J.R., Gilbert, A.T., and O'Connell, A.F., Jr. 2012. Variation in wind and piscivorous predator fields affecting the survival of Atlantic salmon, Salmo salar, in the Gulf of Maine. Fish. Manage. Ecol. 19: 22-35. doi:10.1111/j.1365-2400.2011.00814.x.

Friedland, K.D., Shank, B.V., Todd, C.D., McGinnity, P., and Nye, J.A. 2014. Differential response of continental stock complexes of Atlantic salmon (Salmo salar) to the Atlantic Multidecadal Oscillation. J. Mar. Syst. 133: 7787. doi:10.1016/j.jmarsys.2013.03.003.

Fukuwaka, M., and Kaeriyama, M. 1997. Scale analyses to estimate somatic growth in sockeye salmon, Oncorhynchus nerka. Can. J. Fish. Aquat. Sci. 54(3): 631-636. doi:10.1139/f96-307.

Head, E.J.H., and Sameoto, D.D. 2007. Interdecadal variability in zooplankton and phytoplankton abundance on the Newfoundland and Scotian shelves. Deep Sea Res. 54: 2686-2701. doi:10.1016/j.dsr2.2007.08.003.

Hogan, F., and Friedland, K.D. 2010. Retrospective growth analysis of Atlantic salmon Salmo salar and implications for abundance trends. J. Fish Biol. 76: 2502-2520. doi:10.1111/j.1095-8649.2010.02650.x. PMID:20557605.

Houde, A.L.S., Fraser, D.J., and Hutchings, J.A. 2010. Reduced anti-predator responses in multi-generational hybrids of farmed and wild Atlantic salmon (Salmo salar L.). Conserv. Genet. 11(3): 785-794. doi:10.1007/s10592009-9892-2.

ICES. 2011. Report of the Workshop on Age Determination of Salmon (WKADS), 18-20 January 2011, Galway, Ireland. ICES CM. ACOM:44.

ICES. 2020. Working Group on North Atlantic Salmon (WGNAS). ICES Scientific Reports. 2:21. doi:10.17895/ices.pub.5973.

Izzo, L.K., and Zydlewski, J. 2017. Retrospective analysis of seasonal ocean growth rates of two sea winter Atlantic salmon in eastern Maine using historic scales. Mar. Coast. Fish. 9(1): 357-372. doi:10.1080/19425120.2017. 1334723.

Jacobson, K.C., Teel, D., Van Doornik, D.M., and Casillas, E. 2008. Parasiteassociated mortality of juvenile Pacific salmon caused by the trematode Nanophyetus salmincola during early marine residence. Mar. Ecol. Prog. Ser. 354: 235-244. doi:10.3354/meps07232. 
Jacobson, P., Whitlock, R., Huss, M., Leonardsson, K., Östergren, J., and Gårdmark, A. 2021. Growth variation of Atlantic salmon Salmo salar at sea affects their population-specific reproductive potential. Mar. Ecol. Prog. Ser. 671: 165-174. doi:10.3354/meps13734.

Jonsson, B., and Jonsson, N. 2004. Factors affecting marine production of Atlantic salmon (Salmo salar). Can. J. Fish. Aquat. Sci. 61(12): 2369-2383. doi:10.1139/f04-215.

Juanes, F., Gephard, S., and Beland, K. 2004. Long-term changes in migration timing of adult Atlantic salmon (Salmo salar) at the southern edge of the species distribution. Can. J. Fish. Aquat. Sci. 61(12): 2392-2400. doi:10. 1139/f04-207.

LaCroix, G.L. 2013. Population-specific ranges of oceanic migration for adult Atlantic salmon (Salmo salar) documented using pop-up satellite archival tags. Can. J. Fish. Aquat. Sci. 70(7): 1011-1030. doi:10.1139/cjfas-2013-0038.

Losee, J.P., Miller, J.A., Peterson, W.T., Teel, D.J., and Jacobson, K.C. 2014. Influence of ocean ecosystem variation on trophic interactions and survival of juvenile coho and Chinook salmon. Can. J. Fish. Aquat. Sci. 71(11): 1747-1757. doi:10.1139/cjfas-2014-0043.

Maynard, D.J., and Trial, J.G. 2014. The use of hatchery technology for the conservation of Pacific and Atlantic salmon. Rev. Fish Biol. Fish. 24: 803817. doi:10.1007/s11160-013-9341-7.

MDMR. 2018. Atlantic salmon trap operating and fish-handling protocols. Policy Number A-99-15. Maine Department of Marine Resources Division of Sea Run Fisheries and Habitat, Bangor, Maine.

MERCINA Working Group. 2012. Recent Arctic climate change and its remote forcing of Northwest Atlantic shelf ecosystems. Oceanography, 25(3): 208-213. doi:10.5670/oceanog.2012.60.

Miller, A.S., Miller, T.J., Mills, K.E., and Sheehan, T.F. 2014. Retrospective analysis of Atlantic salmon (Salmo salar) marine growth and condition in the northwest Atlantic based on tag-recovery data. Fish. Oceanogr. 23(2): 103-115. doi:10.1111/fog.12045.

Mills, K.E., Pershing, A.J., Brown, C.J., Chen, Y., Chiang, F.-S., Holland, D.S., et al. 2013a. Fisheries management in a changing climate: lessons from the 2012 ocean heat wave in the Northwest Atlantic. Oceanography, 26(2): 191-195. doi:10.5670/oceanog.2013.27.

Mills, K.E., Pershing, A.J., Sheehan, T.F., and Mountain, D. 2013b. Climate and ecosystem linkages explain widespread declines in North American Atlantic salmon populations. Global Change Biol. 19: 3046-3061. doi:10.1111/gcb.12298.

National Oceanic and Atmospheric Administration National Centers for Environmental Information. 2017. Extended Reconstructed Sea Surface Temperature (ERSST) v5.

National Research Council. 2004. Atlantic salmon in Maine. The National Academies Press, Washington, D.C. doi:10.17226/10892.

Nicieza, A.G., and Metcalfe, N.B. 1997. Growth compensation in juvenile Atlantic salmon: Responses to depressed temperature and food availability. Ecology, 78(8): 2385-2400. doi:10.1890/0012-9658(1997)078[2385:GCIJAS]2.0. $\mathrm{CO} ; 2$.

NMFS and USFWS. 2020. Atlantic salmon (Salmo salar) 5-year review: Summary and evaluation. National Marine Fisheries Service and US Fish and Wildlife Service. Available from https://repository.library.noaa.gov/view/ noaa/27431.

Olmos, M., Massiot-Granier, F., Prévost, E., Chaput, G., Bradbury, I.R., Nevoux, M., and Rivot, E. 2019. Evidence for spatial coherence in time trends of marine life history traits of Atlantic salmon in the North Atlantic. Fish Fish. 20(2): 322-342. doi:10.1111/faf.12345.

Olmos, M., Payne, M.R., Nevoux, M., Prevost, E., Chaput, G., Du Pontavice, H., et al. 2020. Spatial synchrony in the response of a long range migratory species (Salmo salar) to climate change in the North Atlantic Ocean. Global Change Biol. 26: 1319-1337. doi:10.1111/gcb.14913.

Pershing, A.J., Head, E.H.J., Greene, C.H., and Jossi, J.W. 2010. Pattern and scale of variability among Northwest Atlantic Shelf plankton communities. J. Plankton Res. 32(12): 1661-1674. doi:10.1093/plankt/fbq058.

Pershing, A.J., Alexander, M.A., Hernandez, C.M., Kerr, L.A., Le Bris, A., Mills, K.E., et al. 2015. Slow adaptation in the face of rapid warming leads to collapse of the Gulf of Maine cod fishery. Science, 350(6262): 809-812. doi:10.1126/science.aac9819. PMID:26516197.
Pershing, A.J., Mills, K.E., Dayton, A.M., Franklin, B.S., and Kennedy, B.T. 2018. Evidence of adaptation from the 2016 marine heatwave in the Northwest Atlantic Ocean. Oceanography, 31(2): 152-161. doi:10.5670/oceanog.2018.213.

Peyronnet, A., Friedland, K.D., Maoiléidigh, N.Ó., Manning, M., and Poole, W.R. 2007. Links between patterns of marine growth and survival of Atlantic salmon Salmo salar. J. Fish Biol. 71: 684-700. doi:10.1111/j.1095-8649.2007.01538.x.

Pyper, B.J., and Peterman, R.M. 1998. Comparison of methods to account for autocorrelation in correlation analyses of fish data. Can. J. Fish. Aquat. Sci. 55(9): 2127-2140. doi:10.1139/f98-104.

R Core Team. 2020. R: a language and environment for statistical computing. R Foundation for Statistical Computing, Vienna, Austria. Available from https://www.R-project.org.

Reddin, D.G. 1988. Ocean life of Atlantic salmon (Salmo salar L.) in the Northwest Atlantic. In Atlantic salmon. Edited by D. Mills and D. Piggins. Springer, Dordrecht. pp. 483-511. doi:10.1007/978-94-009-1235-9 26.

Renkawitz, M.D., Sheehan, T.F., Dixon, H.J., and Nygaard, R. 2015. Changing trophic structure and energy dynamics in the Northwest Atlantic: implications for Atlantic salmon feeding at West Greenland. Mar. Ecol. Prog. Ser. 538: 197-211. doi:10.3354/meps11470.

Renkawitz, M., Sheehan, T., Rikardsen, A., Righton, D., and Nygaard, R. 2021. Tracking Atlantic salmon off the West Greenland coast and in the Labrador Sea with PSATs. US Dept. Commer., Northeast Fish. Sci. Cent. Tech. Memo. 275. doi:10.25923/sb34-0825.

Rikardsen, A.H., Righton, D., Strøm, J.F., Thorstad, E.B., Garran, P., Sheehan, T., et al. 2021. Redefining the oceanic distribution of Atlantic salmon. Nat. Commun. 11: 12266. doi:10.1038/s41598-021-91137-y.

Saba, V.S., Griffies, S.M., Anderson, W.G., Winton, M., Alexander, M.A., Delworth, T.L., et al. 2016. Enhanced warming of the Northwest Atlantic Ocean under climate change. J. Geophys. Res.: Oceans, 121(1): 118-132 doi:10. 1002/2015JE004832, 10.1002/2015JC011346.

Shearer, W.M. 1992. The Atlantic salmon: natural history, exploitation and future management. John Wiley and Sons Ltd.

Sheehan, T.F., Reddin, D.G., Chaput, G., and Renkawitz, M.D. 2012. SALSEA North America: a pelagic ecosystem survey targeting Atlantic salmon in the Northwest Atlantic. ICES J. Mar. Sci. 69: 1580-1588. doi:10.1093/icesjms/fss052.

Staudinger, M.D., Mills, K.E., Stamieszkin, K., Record, N.R., Hudak, C.A., Allyn, A., et al. 2019. It's about time: A synthesis of changing phenology in the Gulf of Maine ecosystem. Fish. Oceanogr. 28(5): 532-566. doi:10.1111/fog.12429.

Stevens, J.R., Kocik, J.F., and Sheehan, T.F. 2019. Modeling the impacts of dams and stocking practices on an endangered Atlantic salmon (Salmo salar) population in the Penobscot River, Maine, USA. Can. J. Fish. Aquat. Sci. 76(10): 1795-1807. doi:10.1139/cjfas-2018-0225.

Strøm, J.F., Thorstad, E.B., Chafe, G., Sørbye, S.H., Righton, D., Rikardsen, A.H., and Carr, J. 2017. Ocean migration of pop-up satellite tagged Atlantic salmon from the Miramichi River in Canada. ICES J. Mar. Sci. 74(5): 1356-1370. doi:10.1093/icesjms/fsw220.

Thomas, A.C., Pershing, A.J., Friedland, K.D., Nye, J.A., Mills, K.E., Alexander, A., et al. 2017. Seasonal trends and phenology shifts in sea surface temperature on the North American northeastern continental shelf. Elementa Sci. Anthropocene, 5: 48. doi:10.1525/elementa.240.

Thorstad, E.B., Whoriskey, F., Rikardsen, A.H., and Aarestrup, K. 2010. Aquatic nomads: The life and migrations of the Atlantic salmon. In Atlantic salmon ecology. Chapter 1. Edited by Ø. Aas, S. Einum, A. Klemetsen, and J. Skurdal. Blackwell Publishing Professional. pp. 1-32. doi:10.1002/9781444327755.ch1.

Thorstad, E.B., Whoriskey, F., Uglem, I., Moore, A., Rikardsen, A.H., and Finstad, B. 2012. A critical life stage of the Atlantic salmon Salmo salar: Behavior and survival during the smolt and initial post-smolt migration. J. Fish Biol. 81(2): 500542. doi:10.1111/j.1095-8649.2012.03370.x. PMID:22803722.

Tillotson, M.D., Sheehan, T.F., Ellingson, B., Haas-Castro, R.E., Olmos, M., and Mills, K.E. 2021. Non-stationary effects of growth on the survival of North American Atlantic salmon (Salmo salar). ICES J. Mar. Sci. 78(8): 29672982. doi:10.1093/icesjms/fsab174.

USASAC. 2020. Annual Report of the US Atlantic Salmon Assessment Committee, Portland, Maine. Report No. 32 - 2019 Activities. 